\title{
THE CASSAVA MITE COMPLEX. III - NEW DISTRIBUTION RECORDS, MAINLY FROM COLOMBIA AND AFRICA. REFERENCES TO OTHER PLANTS. *
}

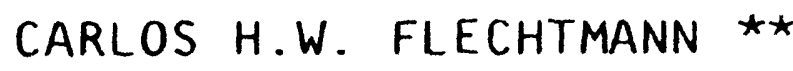

\begin{abstract}
RESUMO
0 complexo dos ácaros da mandioca. 111. Novos dados referentes à sua distribuição, principalmente da Colómbia e Âfrica. Referéncias a outras plantas.

Uma lista de novas referéncias e ocorréncias para ácaros tetraniquí deos da mandioca é apresentada.
\end{abstract}

In addition to the reference presented in instal-
ments nos. 1 and 2 of this series (FLECHTMANN, 1977 ,
1981), the following references to species of spider

* Entregue para publicação em 27/12/1982.

** Departamento de Zoología, E.S.A. "Luiz de Queiroz", USP. 
mites (Acari. Prostigmata, Tetranychidae) from cassavas (Manihot esculenta Crantz, Euphorbiaceae) were found:

1. Tetranychus desertomum Banks, 1900 - Techn. Bull. U.S. Dept. Agric. Div. Entomol. 8: 76.

Collected in Piracicaba, São Paulo, Brasil on cassavas (PASCHOAL, 1968).

2. Tetranychus escolasticae Paschoal, 1970 - An. Esc. Sup. Agric. "Luiz de Queiroz", Piracicaba, SP, 27: 440 .

Collected at Coronel Oviedo, Paraguay, from Manihot utilissima (PASCHOAL, 1968).

3. Oligonychus gossypii (Zacher, 1920) - Ztschr. angew. Entomol. 7: 183.

Reported from Colombia (Bellotti et alii, 1982) on the upper leaf surface of mature cassava leaves where the red mites live between abundant webbing. No damage ascertained.

GUTIERREZ \& ETIENNE (1981) report this species from cassavas (manioc) in Ziguinchor, Sénégal.

4. Eutetranychus banksi (McGregor, 1919) - Proc. U.S. Nat'1. Mus. $56(2303): 644$.

Reported from Colombia; small populations on the upper leaf surface of cassavas. No damage was observed (BELLOTTI et al., 1982).

5. Eutetronychus monodi André, 1954 - Bull. Inst., Fr. Afr. Noire, Sér. A, 16: 859.

GUTIERREZ \& ETIENNE (1981) reported this species from cassavas in Ziguinchor, Senégal. The greenish mites live on the upper leaf surface. 
6. Allonychus brasiliensis (McGregor, 1950)-Amer. Midl. Natur. 44: 318.

BELLOTTI et al. (1982) list this species from cassavas in Colombia. The dark red $\mathrm{mi}$ tes live and feed on the upper leaf surface where they produce some webbing. Consequently, the leaf lobes are curved upward.

7. Aponychus schultzi (Blanchard, 1940) - Rev. Fac. Agron. La Plata 3(2): 24.

A small population of this species was observed on the upper surface of mature leaves on fully grown plants of cassavas in Colombia (BELLOTTI et al., 1982).

8. Atrichoproctus uncinatus Flechtmann, 1967 Doctoral Thesis, Esc. Sup. Agric. "Luiz de Quei roz", Piracicaba, SP: 39.

These dark red mites were found on the upper surfa ce of developed cassava leaves in Colombia (BELLOTTI e $\bar{t}$ al., 1982).

9. Oligonychus thelytokous Gutierrez, 1977- Cah. ORSTOM, sér. Biol., 12 (1): 67.

This is a upper leaf surface feeder; the females are red in colour. Collected from Manihot. Pohl at Port-Laguerre, Nouvelle Calédonie utilissima 1977).

From material recently collected in Africa the following new records were obtained:

1. Mononychellus tanajoa (Bondar, 1938) - Rev. Entomol. Brasil. 9 $(3,4): 44$.

Collections of this mite species from cassavas were submitted by H.R. Herren from Nampula, Moçambique; by R.D. Hennessey from Gandajika and M'Vuazi, Zaire, and, byW.R. Ingram from Serere Research Station, Uganda. 
2. Mononychellus progressivus Doreste, 1981-Bol. Entomol. Venez., $1(10): 123$.

This species was collected on new cassava leaves in N'Toum, Gabom (specimens submitted by E.W. Baker) and in Ogun State, Nigeria.

3. Oligonychus gossypii (Zacher, 1920).

This species was collected from median to old leaves of cassavas in Ogum State, Nigeria; from Manihot glaziovii, M. esculenta, Ixora coccinea, Terminalia sp., Cassia sp., Colocasia antiquomm, and Securinega virosa at IITA, in Ibadan, Nigeria. The red mites live on the upper leaf surface causing discoloration to Manihot and Colocasia leaves and intense bronzing on Ixora and Termi nalia leaves.

4. Eotetranychus ancora Baker E Pritchard, 1960 Hilgardia $29(11): 4$.

This species was collected from Trema guineensis in Ibadan, Nigeria. The greenish mites produce only a small amount of webbing and live on the leaf lower surface cau sing slight bronzing. E. ancora was only known from the type species from Mauritius where it was collected from apple leaves.

5. Eotetranychus monodi Andrē, 1954.

This species is reported for the first time from Nigeria; it was collected from Trema guineensis in Ibadan.

6. Tetranychus neocaledonicus Andrē, 1933 - Bull. Mus. Nat'1. Hist, Nat., Paris, sér. 2, 5: 302.

This species, widespread in Africa, was collected from median leaves of cassavas at IITA, Ibadan, Nigeria. 


\section{LITERATURE CITED}

BELLOTTI, A.C.; REYES, J.A.; GUERRERO, J.M., 1982. ACaros presentes en el cultivo de la yuca y su control. Gula de Estudio, Centro Int'l. Agric. Tropic., Call., Colombia, Serie 04SC - 02.04: 34 pp.

FLECHTMANN, C.H.W., 1978. The cassava mi te complex: Taxo nomy and identification. Proc. Cassava Workshop, CIAT, Cali, Colombia, (7-12 Nov. 1977): 143-153.

FLECHTMANN, C.H.W., 1981. The cassava mite complex. 11. New records and description of two new species in the genus Tetranychus from Asia. Int'l. J. Acarology 7: $81-86$.

GUTIERREZ, J., 1977 - Un tétranyque polyphage de la zone intertropicale: Oligonychus thelytokous n. sp. (Acariens, Tetranychidae). Description et premières données biologiques. Cah. ORSTOM, sér. Biol., 12 (1): 65-72.

GUTIERREZ, J.; ETIENNE, J., 1981. Quelques données sur les acariens Tetranychidae attaquant les plantes cultivées au Sénégal. Agronomie Tropicale, 36(4): 391 394.

PASCHOAL, A.D., 1970. New Brazilian spider mites (Acarina: Tetranychidae). An. Esc. Sup. Agric. "Luiz de Queiroz", 27: 439-455. 
